\title{
Red Blood Cell Cast Measurement
}

National Cancer Institute

\section{Source}

National Cancer Institute. Red Blood Cell Cast Measurement. NCI Thesaurus. Code C74772.

The determination of the amount of red blood cell casts present in a urine sample. 